\title{
Influence of Planting Methods on Production of Suckers (Rhizome or Propagative Material), Essential Oil Yield, and Quality of Menthol Mint (Mentha arvensis L.)
}

\author{
Devendra Kumar, Rakesh Kumar, Anil Kumar Singh, Kirti Verma, \\ Kushal Pal Singh, Nilofer, Anuj Kumar, Parminder Kaur, Anjali Singh, \\ Janhvi Pandey, Puja Khare and Saudan Singh*
}

Division of Agronomy \& Soil Science, CSIR-Central Institute of Medicinal and Aromatic
Plants PO- CIMAP, Lucknow-220615, India

*Corresponding author

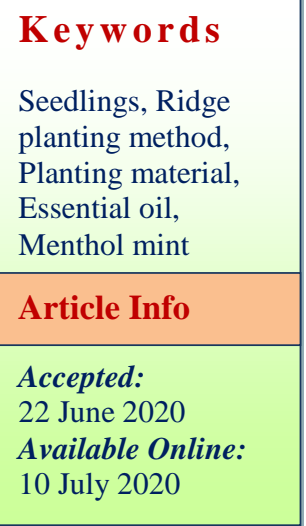

A B S T R A C T

\begin{abstract}
Menthol mint (Mentha arvensis L.) is a commercially cultivated crop and essential oil-bearing plant that belongs to family Lamiaceae, and it is used in aromatherapy, flavor, and pharmaceutical industries. The aims of the present study to optimize planting methods, age of seedlings, and date of harvesting. The experiment was carried out at the research farm of CSIR-Central Institute of Medicinal and Aromatic Plants, Lucknow during the year 2014-2015 and 2015-2016.The analysis was consisting of three planting methods, five age of seedlings, and four dates of harvesting. Results were revealed that ridge planting recorded maximum sucker yield $\left(27.50 \mathrm{Mg} \mathrm{ha}^{-1}\right)$, essential oil yield $\left(52.97 \mathrm{~kg} \mathrm{ha}^{-1}\right)$ with minimum water requirement, and maximum water use efficiency $(48.22 \mathrm{ha} \mathrm{cm}$ and $0.43 \mathrm{~kg}$ ha $\mathrm{mm}^{-1}$ ) along with net returns (\$ $\left.3590.34 \mathrm{ha}^{-1}\right)$. The 30 days old seedlings produced the highest suckers and essential oil yield $\left(27.43 \mathrm{Mg} \mathrm{ha}^{-1}\right.$ and $56.62 \mathrm{~kg}$ $\mathrm{ha}^{-1}$ ) along with the maximum net profits $\left(\$ 3598.44 \mathrm{ha}^{-1}\right)$. Maximum suckers and essential oil yield $\left(25.10 \mathrm{Mg} \mathrm{ha}^{-1}\right.$ and $\left.50.85 \mathrm{kgha} \mathrm{mm}^{-1}\right)$ with higher net return $(\$$ $3206.22 \mathrm{ha}^{-1}$ ) were reported when harvesting (digging) of suckers on 31 January. Planting on ridges of 30 days old seedlings along with harvesting on 31 January was a suitable combination to obtain maximum suckers and essential oil yield with higher income.
\end{abstract}

\section{Introduction}

India is a leading country in the production and export of mentholmint in terms of essential oil (Rakesh et al., 2019). Menthol mint reproduces by vegetative propagation means through underground parts, which is called a sucker. It is growing at a depth of 15 
$\mathrm{cm}$ and spread in a multi-direction (Sukhmal et al., 2004). Menthol mint is an essential industrial crop and produced during the summer season in the northern Indian plains and plays a significant role not only to make the farmers of this region prosperous but also has established India as a world leader in mentholmint production. The area under mentholmint cultivation in India is estimated to be $2.5-3.0$ lakh hectares, with an annual output of 25000-30000 metric tons of essential oil. The major constraint for the cultivation of this crop is the unavailability of suckers (planting material or rhizome) in sufficient quantity. There is a requirement of about 20,000-30,000metrics tonnes of planting materials, but the production of quality planting material is much less for the cultivation of menthol mint.

The conventional method used for sucker production requires more time, land, labor, and other resources. More time needed for planting material production leads to shortening the cropping period of menthol mint (Mentha arvensis L.) because it is cultivated in different cropping systems like after paddy, pea, mustard, potato, wheat and harvested before the onset of monsoon in India (Nilofer et al., 2015). However, sucker or rhizome production with higher quantity and quality can be possible by ridge bed planting methods. It is reported that the ridge and furrow irrigated raised bed method are the water-conserving techniques in different crops leading to more production over flat bed planting. Likewise, It has been proven by many workers which include Tian et al., (2003); Gan et al., (2013); Zhou et al., (2009); Ren et al., (2016); Yaseen et al., (2013), and Singh et al., (2003) who worked on various traditional crops as well as medicinal and aromatic crops like, Triticum aestivum L., Solanum tuberosum L., Zeamaize L., Chlorophytum borivilianum, and Mentha citrate L., etc. The crop growth can be enhanced by using healthy seedlings of proper age, and this imparts effects on production planting material (Jellani et al., 2015). The time of harvesting or digging forthe production of planting materialin menthol mint playsa crucial role in enhancing the yield. Hence, farmers are forced to go for direct planting material sowing, which is less profitable as compared with the transplanted crop.

In the present investigation, the emphasis was given for developing an appropriate method of productivity of planting material (rhizome) for menthol mint. The aims of these studies were i) to enhance the productivity of planting material with better quality and reduction in cropping periods as well as inputs ii) to develop a cost-effective agro practice for planting material and essential oil production in northern Indian plains.

\section{Materials and Methods}

\section{Field study area and climatic characteristic}

The field experiment was conducted in the (from July-January in 2014-15 and 2015-16) at the experimental farm of CSIR-Central Institute of Medicinal and Aromatic Plants, Lucknow. The research station $\left(26^{\circ} 5^{\prime} \mathrm{N}, 80^{\circ}\right.$ $5^{\prime} \mathrm{E}$ ) is located at about $123 \mathrm{~m}$ above sea level, in the northern part of India, and having a semi-humid climate with hot summers and cool winters. This site is classified as semiarid subtropical, along with hot summers and cool winters. Monsoon sets typically from June to September, along with average annual rainfall is $700 \mathrm{~mm}$. The average weather of a two-year data set is depicted in Fig. 1. The soil of the experimental field at 0-30 cm depth was sandy loam in texture, and having $\mathrm{pH} 7.7$, EC of $3.36 \mathrm{dS} \mathrm{m} \mathrm{m}^{-1}$ contains total Nitrogen (780 mg kg ${ }^{-1}$ ), Phosphorus (13 $\mathrm{mg} \mathrm{kg}^{-1}$ ), and Potash (386 mg kg-1). 


\section{Experimental design}

A three-factor experiment was set up in a split-plot design with replications in thrice. Experimental treatments were consisting of three planting methods viz., i) flatbed planting, ii) furrow irrigated raised bed (FIRB), and iii) ridge bed planting, five plants age were taken after the first harvest of the main crop, i.e., i) 20 days, ii) 30 days, iii) 40 days, iv) 50 days, and v) 60 days old)along with four harvesting dates viz., i) 15 December, ii) 31 December, iii) 15January, and, iv) 31 January as an individual plot size $2.4 \mathrm{~m}^{2} \times 3.6 \mathrm{~m}^{2}=8.64 \mathrm{~m}^{2}$. There were no types of herbicides that were applied during the experimental period, and then weeding was done manually as per need.

\section{Field preparation and transplanting}

Field preparation for transplanting of seedling was done on the basis of treatment, respectively, at the study site. Flat beds were prepared using the method of popular Check Basin, and furrow irrigated raised beds were made manually with the help of shovels, and ridges were prepared by using a mechanical ridge maker machine. The seedlings were transplanted as per the mentioned seedling ageon (15 August) in both the experimental years and as soon as the irrigation was given until water reached the root zone of each seedling. The seedling was taken from harvested of the previously harvested crop in the second fortnight of May, and there is about $400-600 \mathrm{~m}^{2}$ field left to obtain seedlings about the one-hectare plantation. Transplanting was done in spacing between the line to line and plant to plant, which was maintained at $60 \times 30 \mathrm{~cm}$ apart. For this spacing, about 0.055 million seedlings were required for one-hectare commercial plantation. No herbicides were applied during the course of trials, and weeding was done manually when necessary. Chemical fertilizers were used at $120 \mathrm{~kg} \mathrm{~N}_{2}, 60 \mathrm{~kg} \mathrm{P}_{2} \mathrm{O}_{5}$, and $60 \mathrm{~kg} \mathrm{~K} \mathrm{~K}_{2} \mathrm{O}$ in the form of urea, DAP (diammonium phosphate), and MOP (muriate of potash) in a hectare during experimentation.

\section{Data collection}

Growth attributes, plant sampling and biometric observation

Plant height, plant spread, sucker length, sucker yield, and essential oil yield were determined by randomly selected ten plants of each plot. The plant was harvested from the 2 $\mathrm{cm}$ above the ground, and the data on fresh weight, essential oil content, dry weight, and leaf: stem ratio were recorded individually per plant basis. The length of rhizomes was measured with the help of measuring scale during each date of harvesting.

\section{Harvesting}

The harvesting was done after 120, 135, 150, and 180 days of transplanting with respect to other treatments. For the estimation of herb and rhizome, yield harvesting was done as per treatment, and the total yield of each experimental plot was calculated in kilograms. Further, the weight sample plant was also considered in the herb yield. The rhizome was recorded by uprooting the plants from individual experimental plots and then converted into yieldplant ${ }^{-1}$ and $\mathrm{Mg} \mathrm{ha}^{-1}$.

\section{Water requirement and water use efficiency}

Water requirement was worked out by multiplication of depth of irrigation water applied each irrigation with the number of irrigations. In addition, water use efficiency (WUE) $\mathrm{kg}$ ha $\mathrm{mm}^{-1}$ was calculated by using the following Eq. 1(Singh et al., 1997).

WUE $=\frac{\text { Yield } \mathrm{kg} / \mathrm{ha}}{\text { Water applied (ha } \mathrm{cm})}$ 
Whereas, irrigated water expressed in ha $\mathrm{cm}$ (irrigation water applied + precipitation during the cropping period+ effective rainfall).

\section{Extraction of essential oil}

For the estimation of essential oil percentage in fresh herb yield, a sampled plant was used from each experimental plot. The essential oil percentage was estimated by hydrodistillation methods using Clevenger's types of apparatus (Clevenger, J.F., 1928). After three $h$ distillation, essential oils were collected in vials and dehydrated with sodium sulfate $\left(\mathrm{Na}_{2} \mathrm{SO}_{4}\right)$ using the method of (Guenther et al., 1961). Essential oil percentage (w/w\%) and yield $\left(\mathrm{kg} \mathrm{ha}^{-1}\right)$ were determined through multiplied the value in the herb yield.

\section{Quality analysis of essential oil}

Essential oil quality was measured through a gas chromatograph (Perkin Elmer Auto system XL GC fitted with Elite wax column (30 $\mathrm{m} \times 0.25 \mathrm{~mm} \times 0.25 \mu \mathrm{m}$ film thickness). The oven temperature was programmed from $40{ }^{\circ} \mathrm{C}\left(40-120\right.$ at the rate of $\left.3^{\circ} \mathrm{Cmin}^{-1}\right)$ with 9 minutes hold, $120-140^{\circ} \mathrm{C}$ for $2{ }^{\circ} \mathrm{Cmin}^{-1}$ with 2-minute hold, and $140-250{ }^{\circ} \mathrm{C}$ at $5^{\circ} \mathrm{Cmin}^{-1}$ with 2 minutes final hold time. Hydrogen gas was used as the carrier gas at 7.5 psi constant column head pressure; the split ratio was 1:40, injection size $0.02 \mu l$ neat and clean; injector and detector temperatures were maintained at $250{ }^{\circ} \mathrm{C}$. The characterization of constituents was done based on co-injection with standards (Sigma-Aldrich) along with hydrocarbons

\section{Economics}

The total cost of cultivation was calculated by considering the general cost of inputs. Total income was workout by examining the current value of output and selling price of rhizome@0.14 \$ per kg. The selling price of essential oil @ 14.58 \$ per kg, net income was calculated by deducting the cost of cultivation from gross return (Sharma et al., 2019).

\section{Statistical analysis}

The analysis of the experiment was done using excel Windows-10 home Single languages (C) 2019 Microsoft Corporation. The data were subjected to two-way analysis (ANOVA), and the difference between treatment means was separated using the least significant difference test (LSD) (SAS Institute, 2003). A significance level of 95\% was applied according to (Little and Hills 1978).

\section{Results and Discussion}

Planting methods, age of seedlings, and dates of harvesting (digging) were considered for evaluating the growth, yield, water requirement, and economics of menthol mint.

\section{Morphological characteristics and yield}

\section{Effect of planting method}

Growth attributes of Mentha arvensis L. are influenced by the planting method, age of seedling, and harvesting dates (Table 1). Planting methods are the most critical aspects of growth attributes which not only ensure better crop establishment but also result in efficient utilization of irrigation water, especially when the crop was transplanting on the ridge. Hence, planting methods, age of seedlings, and effect of date of harvesting (digging) was also evaluated in terms of growth attributes, yield (rhizomes and essential oil), water requirement and water use efficiency. The highest plant height (50 $\mathrm{cm})$, plant spread $(64.39 \mathrm{~cm})$, and length of sucker $(31.27 \mathrm{~cm})$ were obtained from ridge 
planting as compared with FIRB and flatbed planting method. Similarly, maximum rhizome yield $\left(184.23 \mathrm{~g} \mathrm{plant}^{-1}\right.$ and $27.5 \mathrm{Mg}$ $\mathrm{ha}^{-1}$ ) was recorded under ridge planting, and it was minimum (157.61g plant ${ }^{-1}$ and 17.5 $\mathrm{Mg} \mathrm{ha}{ }^{-1}$ ) under flatbed planting. Similarly, that maximum herb yield $\left(7.56 \mathrm{Mgha}^{-1}\right)$, essential oil content $(0.62 \%)$, essential oil yield $\left(46.92 \mathrm{~kg} \mathrm{ha}^{-1}\right)$, and menthol content (74.12\%) were shown at ridge planting (Table 2). In contrast, the lowest herb yield $(5.01 \mathrm{Mg}$ $\left.\mathrm{ha}^{-1}\right)$, essential oil content $(0.60 \%)$, essential oil yield $\left(30.08 \mathrm{~kg} \mathrm{ha}^{-1}\right)$, and menthol content $(71.21 \%)$ obtained at flatbed planting method.

\section{Effect of age of seedling}

Maximum plant height $(50.06 \mathrm{~cm})$, plant spread $(64.87 \mathrm{~cm})$, rhizome length $(30.96$ $\mathrm{cm})$, and rhizome yield (184.07 $\mathrm{g}$ plant $^{-1}$ and $27.43 \mathrm{M} \mathrm{ha}^{-1}$ ) were recorded at 30 days old seedling as compared with other age of seedlings (Table 1). In contrast, minimum plant height $(46.07 \mathrm{~cm})$, plant spread $(59.28$ $\mathrm{cm})$, rhizome length $(28.48 \mathrm{~cm})$, and rhizome yield $\left(156.16 \mathrm{~g} \mathrm{plant}^{-1}\right.$ and16.9 $\left.\mathrm{Mg} \mathrm{ha}^{-1}\right)$ obtained in 60 days old seedlings. Similarly, the 30 days old seedlings recorded significantly maximum herb yield $(8.71 \mathrm{Mg}$ $\left.\mathrm{ha}^{-1}\right)$, essential oil content $(0.61 \%)$, essential oil yield (53.13 kg ha $\left.{ }^{-1}\right)$, and menthol content $(73.21 \%)$ were observed at 30 days old seedlings (Table 2). In contrast, the essential oil content $(0.63 \%)$ was highest at 20 days old seedlings, but due to the highest fresh herb yield, oil yield was recorded in 30-day old seedlings.

\section{Effect of date of harvesting}

The harvesting of menthol mint on 31 January was reported the significantly maximum plant height $(49.13 \mathrm{~cm})$, rhizome length $(30.74 \mathrm{~cm})$, rhizome yield $\left(177.65 \mathrm{~g} \mathrm{plant}^{-1}\right.$ and $25.10 \mathrm{Mg}$ $\left.\mathrm{ha}^{-1}\right)$, herb yield (7.26 $\left.\mathrm{Mg} \mathrm{ha}^{-1}\right)$, essential oil content $(0.64 \%)$, essential oil yield $(46.49 \mathrm{~kg}$ $\left.\mathrm{ha}^{-1}\right)$, and menthol content (73.44\%)as compared with others treatments of harvesting dates (Table $1 \& 2$ ). However, minimum plant height $(47.13 \mathrm{~cm})$, rhizome length $(28.59 \mathrm{~cm})$, rhizome yield $\left(163.59 \mathrm{~g} \mathrm{plant}^{-1}\right.$, and $19.60 \mathrm{Mg}$ $\mathrm{ha}^{-1}$ ) was recorded under the digging date of 15 December.

\section{Interaction effect on fresh herb yield}

The $(\mathrm{M} \times \mathrm{A})$ interaction effect was found significant in herb yield, which is depicted in Table 4. Maximum herb yield (10.62 $\mathrm{Mg} \mathrm{ha}^{-1}$ ) was recorded under treatment combination of ridge bed planting and 30 days old seedlings.

\section{Water requirement and water use efficiency}

Significantly, minimum water requirement (48.22 ha $\mathrm{cm})$ and maximum water use efficiency $\left(0.43 \mathrm{~kg} \mathrm{ha} \mathrm{mm}^{-1}\right)$ were obtained under ridge planting followed by FIRB (55.71 ha $\mathrm{cm}$ and $0.36 \mathrm{~kg}$ ham $\mathrm{m}^{-1}$ ) and flatbed planting method (70.69 ha $\mathrm{cm}$ and $0.33 \mathrm{~kg}$ hamm $^{-1}$ ). Data further revealed that the maximum utilization of irrigation water and minimum water use efficiency had significantly observed with the flat bed planting method.

Irrigation water requirement of menthol mint production was also considered for using seedlings age. Results indicate that water requirement $(58.21 \mathrm{ha} \mathrm{cm})$ was similar to all ages of seedlings, i.e., 20, 30, 40, 50, and 60 days old seedlings. In contrast, maximum water use efficiency $\left(0.41 \mathrm{~kg} \mathrm{hamm}^{-1}\right)$ was observed under 30 days old seedlings, which was significantly superior to other age of seedlings. Minimum water use efficiency was observed under 60 days old seedlings (Table 2).

Data presented in (Table 2) depicted that water requirement and water use efficiency 
menthol mint was significantly affected by different harvesting dates. Among the date of harvesting (digging) minimum water requirement $(52.97 \mathrm{ha} \mathrm{cm})$ and maximum water use efficiency $\left(0.38 \mathrm{~kg}\right.$ ha mm $\left.\mathrm{mm}^{-1}\right)$ were observed under 15 December as compared with other treatments of harvesting date, respectively. However, the highest water requirement $(68.10 \mathrm{ha} \mathrm{cm})$ and lowest water use efficiency $\left(0.37 \mathrm{~kg} \mathrm{hamm}{ }^{-1}\right)$ were recorded under 31 January harvesting (digging) date as compared with 15January, 31 December and 15December respectively.

Table.1 Morphological traits and sucker yield as affected by planting method, age of seedlings and date of digging in Mentha arvensis $\mathrm{L}$.

\begin{tabular}{|c|c|c|c|c|c|}
\hline Treatments & $\begin{array}{c}\text { Plant } \\
\text { Height }(\mathbf{c m})\end{array}$ & Plant spread (cm) & Sucker length $(\mathrm{cm})$ & $\begin{array}{l}\text { Sucker yield } \\
\left(\text { g plant }^{-1}\right)\end{array}$ & $\begin{array}{c}\text { Sucker yield } \\
\left(\mathrm{Mg} \mathrm{ha}^{-1}\right)\end{array}$ \\
\hline \multicolumn{6}{|c|}{ Method of Planting } \\
\hline Flat bed planting & 46.00 & 59.52 & 28.06 & 157.61 & 17.52 \\
\hline FIRB & 48.34 & 62.20 & 29.77 & 163.05 & 19.54 \\
\hline Ridge bed planting & 50.00 & 64.39 & 31.27 & 184.23 & 27.51 \\
\hline $\operatorname{SEm} \pm$ & 0.10 & 0.12 & 0.08 & 0.72 & 0.18 \\
\hline LSD $(\leq 0.05)$ & 0.28 & 0.35 & 0.23 & 1.99 & 0.51 \\
\hline \multicolumn{6}{|l|}{ Age of Seedlings } \\
\hline 20 days old & 49.47 & 63.46 & 30.29 & 172.87 & 23.21 \\
\hline 30 days old & 50.06 & 64.87 & 30.96 & 184.07 & 27.43 \\
\hline 40 days old & 48.02 & 61.88 & 29.67 & 167.00 & 21.10 \\
\hline 50 days old & 46.96 & 60.69 & 29.12 & 161.40 & 18.99 \\
\hline 60 days old & 46.07 & 59.28 & 28.48 & 156.16 & 16.90 \\
\hline SEm \pm & 0.05 & 0.07 & 0.03 & 0.32 & 0.61 \\
\hline LSD $(\leq 0.05)$ & 0.10 & 0.13 & 0.06 & 0.66 & 1.25 \\
\hline \multicolumn{6}{|l|}{ Harvesting (Digging) } \\
\hline 15 December & $47.13^{\mathrm{d}}$ & 63.74 & $28.59^{d}$ & 163.59 & 19.60 \\
\hline 31 December & $47.86^{c}$ & 62.79 & $29.34^{\mathrm{c}}$ & 164.59 & 20.00 \\
\hline 15 January & $48.35^{b}$ & 61.48 & $30.14^{\mathrm{b}}$ & 167.36 & 21.30 \\
\hline 31 January & $49.13^{\mathrm{a}}$ & 60.13 & $30.74^{\mathrm{a}}$ & 177.65 & 25.10 \\
\hline SEm \pm & 0.01 & 0.02 & 0.01 & 0.09 & 0.53 \\
\hline LSD $(\leq \mathbf{0 . 0 5})$ & 0.02 & 0.04 & 0.02 & 0.17 & 1.06 \\
\hline \multicolumn{6}{|l|}{ Interaction } \\
\hline $\mathbf{M} \times \mathbf{A}$ & NS & NS & NS & NS & NS \\
\hline $\mathbf{M} \times \mathbf{D}$ & NS & NS & NS & NS & NS \\
\hline $\mathbf{D} \times \mathbf{A}$ & NS & NS & NS & NS & NS \\
\hline$M \times \mathbf{A} \times \mathbf{D}$ & NS & NS & NS & NS & NS \\
\hline
\end{tabular}

Letters showing the difference $(* \mathrm{P}>0.05)$, FIRB $=$ Furrow irrigated raised bed, $\mathrm{M}=$ Planting method, $\mathrm{A}=\mathrm{Age}$ of seedling, $\mathrm{D}=$ Date of harvesting (digging), NS = Non significant 
Table.2 Fresh herb yield, oil content, oil yield, menthol content, water requirement and water use efficiency as affected by planting methods, age of seedlings and date of

digging in Mentha arvensis $\mathrm{L}$.

\begin{tabular}{|c|c|c|c|c|c|c|}
\hline Treatments & $\begin{array}{c}\text { Herb yield } \\
\left(\mathrm{Mg} \mathrm{ha}^{-1}\right)\end{array}$ & $\begin{array}{c}\text { Essential } \\
\text { oil content } \\
(\%)\end{array}$ & $\begin{array}{c}\text { Essential } \\
\text { oil yield } \\
\left(\mathrm{Kg} \mathrm{ha}^{-1}\right)\end{array}$ & $\begin{array}{c}\text { Menthol } \\
\text { content } \\
(\%)\end{array}$ & $\begin{array}{c}\text { Water } \\
\text { requireme } \\
\text { nt (ha cm) }\end{array}$ & $\begin{array}{c}\text { WUE } \\
\text { kg ha } \mathrm{mm}^{-1} \text { ) }\end{array}$ \\
\hline \multicolumn{7}{|l|}{ Methods of planting } \\
\hline Flat bed planting & $5.01^{\mathrm{c}}$ & $0.60^{c}$ & 30.08 & 71.21 & 70.69 & 0.33 \\
\hline FIRB & $6.00^{\mathrm{b}}$ & $0.61^{\mathrm{ab}}$ & 36.62 & 72.55 & 55.71 & 0.36 \\
\hline Ridge bed planting & $7.57^{\mathrm{a}}$ & $0.62^{\mathrm{a}}$ & 46.92 & 74.12 & 48.22 & 0.43 \\
\hline SEm \pm & 0.07 & 0.02 & 1.57 & 0.26 & 2.63 & 0.001 \\
\hline LSD ( $\leq \mathbf{0 . 0 5})$ & 0.20 & 0.06 & 4.37 & 0.71 & 7.31 & 0.002 \\
\hline \multicolumn{7}{|l|}{ Age of seedlings } \\
\hline 20 days old & $6.18^{b}$ & 0.63 & 38.91 & 72.11 & 58.21 & 0.38 \\
\hline 30 days old & $8.71^{\mathrm{a}}$ & 0.61 & 53.13 & 73.21 & 58.21 & 0.41 \\
\hline 40 days old & $5.64^{c}$ & 0.61 & 34.38 & 71.08 & 58.21 & 0.37 \\
\hline 50 days old & $5.33^{\mathrm{cd}}$ & 0.60 & 31.97 & 70.11 & 58.21 & 0.36 \\
\hline 60 days old & $5.12^{\mathrm{e}}$ & 0.60 & 30.74 & 68.98 & 58.21 & 0.35 \\
\hline SEm \pm & 0.13 & 0.02 & 2.33 & 0.30 & 0.61 & 0.001 \\
\hline LSD $(\leq \mathbf{0 . 0 5})$ & 0.27 & 0.04 & 4.80 & 0.62 & 1.25 & 0.002 \\
\hline \multicolumn{7}{|l|}{ Harvesting (Digging) } \\
\hline 15 December & $5.63^{d}$ & 0.60 & 33.79 & 70.79 & 52.97 & 0.38 \\
\hline 31 December & $5.76^{c}$ & 0.60 & 34.54 & 71.11 & 54.13 & 0.38 \\
\hline 15 January & $6.13^{b}$ & 0.60 & 36.76 & 72.14 & 57.63 & 0.38 \\
\hline 31 January & $7.26^{\mathrm{a}}$ & 0.64 & 46.49 & 73.44 & 68.10 & 0.37 \\
\hline SEm \pm & 0.10 & 0.02 & 1.52 & 0.27 & 1.23 & 0.001 \\
\hline CD $(5 \%)$ & 0.19 & 0.03 & 3.02 & 0.54 & 2.45 & 0.002 \\
\hline \multicolumn{7}{|l|}{ Interaction } \\
\hline $\mathbf{M} \times \mathbf{A}$ & $*$ & NS & NS & NS & NS & NS \\
\hline $\mathbf{M} \times \mathbf{D}$ & NS & NS & NS & NS & NS & NS \\
\hline $\mathbf{D} \times \mathbf{A}$ & NS & NS & NS & NS & NS & NS \\
\hline $\mathbf{M} \times \mathbf{A} \times \mathbf{D}$ & NS & NS & NS & NS & NS & NS \\
\hline
\end{tabular}

Letters showing the difference $(* \mathrm{P}>0.05)$, FIRB $=$ Furrow irrigated raised bed, $\mathrm{M}=$ Planting method, $\mathrm{A}=\mathrm{Age}$ of seedling, $\mathrm{D}=\mathrm{Date}$ of harvesting (digging), NS = Non-significant, ${ }^{*}=$ Significant 
Table.3 Economics as affected by planting methods, age of seedlings and date of digging in Mentha arvensis L.

\begin{tabular}{|c|c|c|c|c|}
\hline Treatments & $\begin{array}{c}\text { Cost of } \\
\text { cultivation } \\
\left(\$ \text { ha }^{-1}\right)\end{array}$ & $\begin{array}{l}\text { Gross } \\
\text { income } \\
\left(\$ \text { ha }^{-1}\right)\end{array}$ & $\begin{array}{l}\text { Net income } \\
\qquad\left(\$ \mathbf{h a}^{-1}\right)\end{array}$ & $\begin{array}{c}\text { B:C ratio } \\
(\%)\end{array}$ \\
\hline \multicolumn{5}{|l|}{ Methods of planting } \\
\hline Flat bed planting & 505.09 & 2554.39 & 2049.30 & 4.06 \\
\hline FIRB & 441.83 & 2849.66 & 2407.83 & 5.45 \\
\hline Ridge bed planting & 420.45 & 4010.79 & 3590.34 & 8.54 \\
\hline \multicolumn{5}{|l|}{ Age of seedlings } \\
\hline 20 days old & 462.60 & 3384.66 & 2922.06 & 6.32 \\
\hline 30 days old & 401.56 & 4000.00 & 3598.44 & 8.96 \\
\hline 40 days old & 464.71 & 3076.99 & 2612.28 & 5.62 \\
\hline 50 days old & 473.64 & 2768.30 & 2294.66 & 4.84 \\
\hline 60 days old & 476.44 & 2464.28 & 1987.83 & 4.17 \\
\hline \multicolumn{5}{|l|}{ Harvesting (Digging) } \\
\hline 15 December & 423.85 & 2854.18 & 2430.33 & 5.73 \\
\hline 31 December & 458.31 & 2917.03 & 2458.72 & 5.36 \\
\hline 15 January & 470.20 & 3104.84 & 2634.65 & 5.60 \\
\hline 31 January & 470.80 & 3677.02 & 3206.22 & 6.81 \\
\hline
\end{tabular}

FIRB $=$ Furrow irrigated raised bed, $\mathrm{M}=$ Planting method, $\mathrm{A}=$ Age of seedling,

$\mathrm{D}=$ Date of harvesting (digging)

Table.4 Fresh herb yields as affected by interaction effect on planting methods and age of seedlings on Mentha arvensis L.

\begin{tabular}{|l|c|c|c|c|c|c|}
\hline $\begin{array}{l}\text { Method } \times \text { Age } \\
\text { of seedling }\end{array}$ & $\begin{array}{c}\text { 20 days } \\
\text { old } \\
\text { seedling }\end{array}$ & $\begin{array}{c}\text { 30 days } \\
\text { old } \\
\text { seedling }\end{array}$ & $\begin{array}{c}40 \text { days } \\
\text { old } \\
\text { seedling }\end{array}$ & $\begin{array}{c}\text { 50 days } \\
\text { old } \\
\text { seedling }\end{array}$ & $\begin{array}{c}\text { 60 days } \\
\text { old } \\
\text { seedling }\end{array}$ & Averages \\
\hline Flat beb planting & $4.98^{\mathrm{c}}$ & $7.05^{\mathrm{c}}$ & $4.56^{\mathrm{c}}$ & $4.31^{\mathrm{c}}$ & $4.15^{\mathrm{c}}$ & $5.01^{\mathrm{c}}$ \\
\hline FIRB & $5.96^{\mathrm{b}}$ & $8.44^{\mathrm{b}}$ & $5.46^{\mathrm{b}}$ & $5.16^{\mathrm{b}}$ & $4.97^{\mathrm{b}}$ & $6.04^{\mathrm{b}}$ \\
\hline Ridge bed planting & $7.58^{\mathrm{a}}$ & $10.62^{\mathrm{a}}$ & $6.87^{\mathrm{a}}$ & $6.50^{\mathrm{a}}$ & $6.25^{\mathrm{a}}$ & $7.57^{\mathrm{a}}$ \\
\hline Average & 6.17 & 8.71 & 5.63 & 5.32 & 5.12 & 6.19 \\
\hline For comparison of mean & $\mathrm{S} . \mathrm{Em} \pm$ & $\mathrm{CD}(5 \%)$ & & & \\
\hline Planting method (M) & 0.071 & 0.19 & & & \\
\hline Age of seedlings (A) & 0.131 & 0.27 & & & \\
\hline M at same level of (A) & 0.22 & 0.46 & & & \\
\hline $\begin{array}{l}\text { A at same or different level of } \\
\text { (M) }\end{array}$ & 1.57 & 3.37 & & & \\
\hline
\end{tabular}

Letters showing the difference $(* \mathrm{P}>0.05)$, FIRB $=$ Furrow irrigated raised bed, $\mathrm{M}=$ Planting method, $\mathrm{A}=$ Age of seedling, $\mathrm{D}=$ Date of harvesting (digging) 
Fig.1 Mean of standard fortnight air temperature (C), relative humidity (\%), sunshine hours (hrs) and total rainfall (mm) over the cropping season 2014- 15 and 2015-16

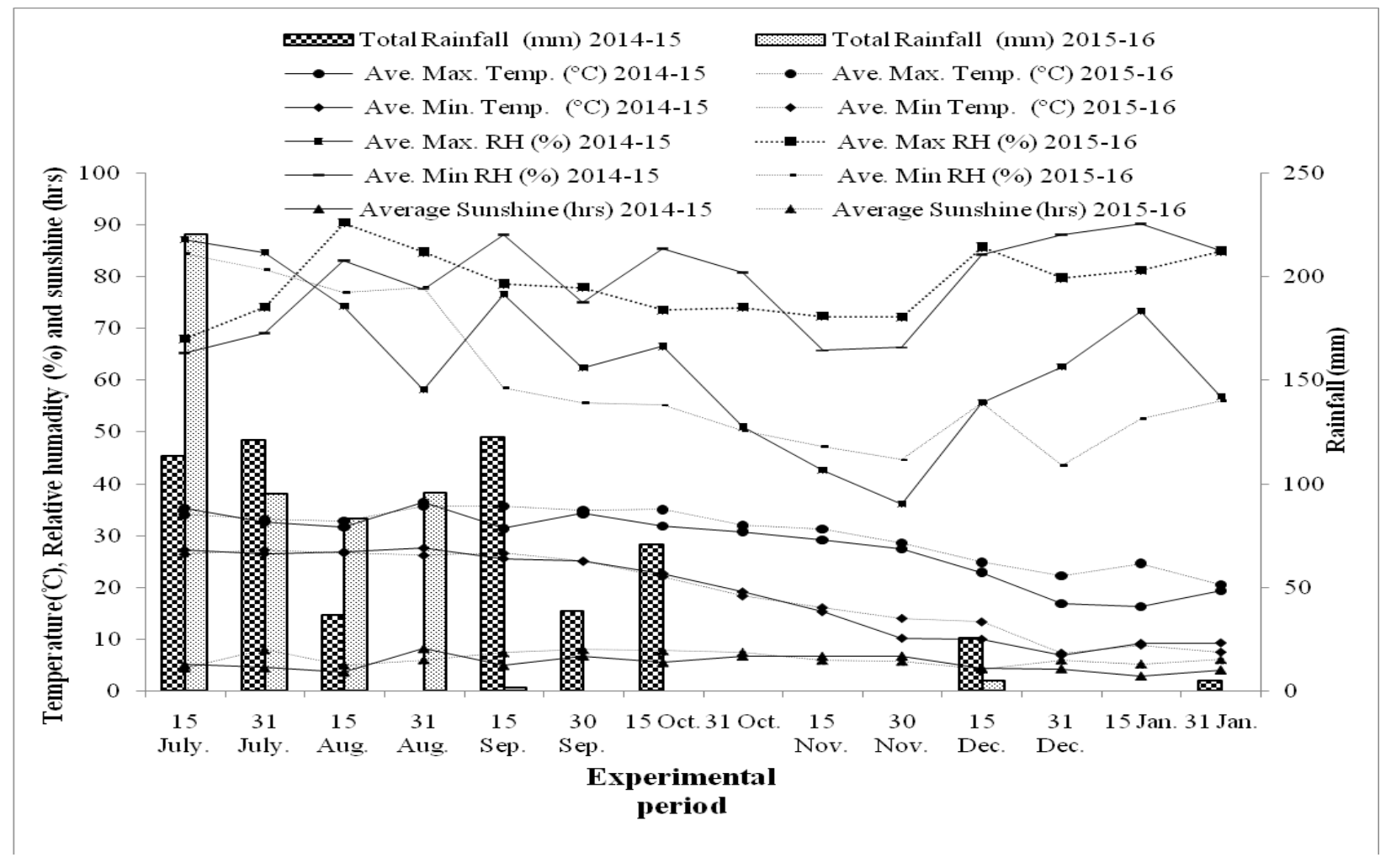

Fig.2a Sketch of flat bed planting for sucker (rhizomes or propagative materials) and essential oil yield

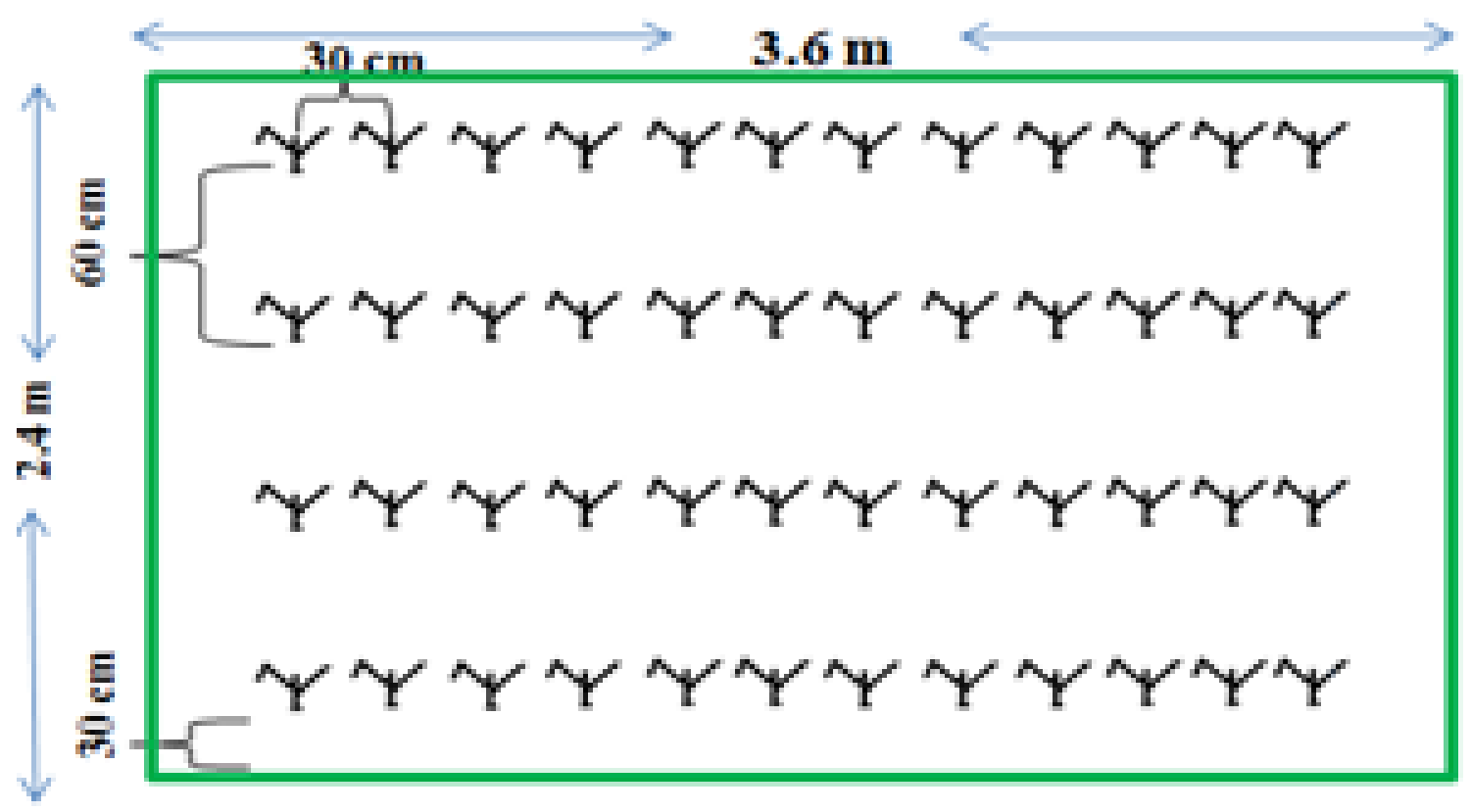


Fig.2b Sketch of furrow irrigated raised bed planting for sucker (rhizomes or propagative materials) and essential oil yield

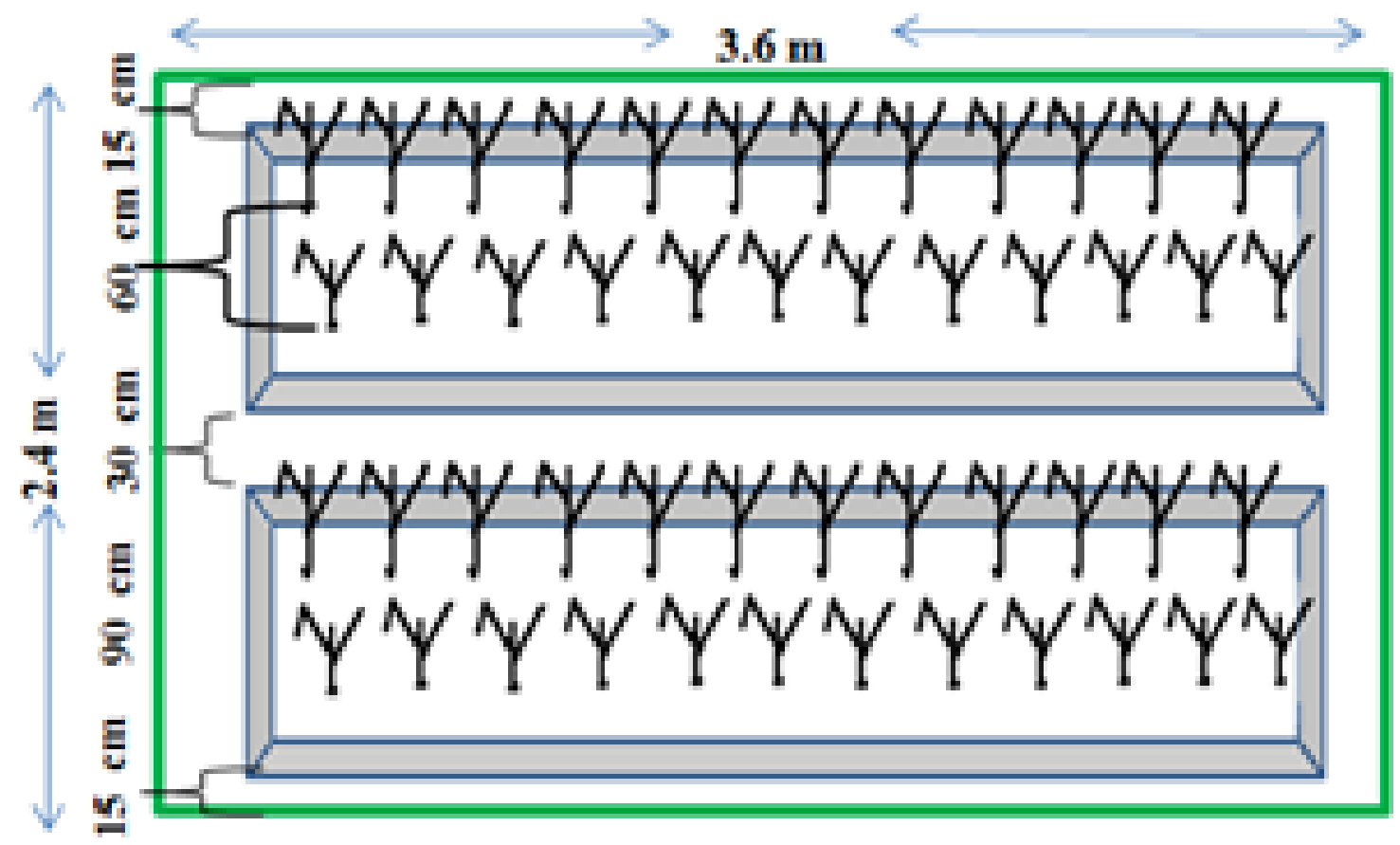

Fig.2c Sketch of ridge planting for sucker (rhizomes or propagative materials) and essential oil yield

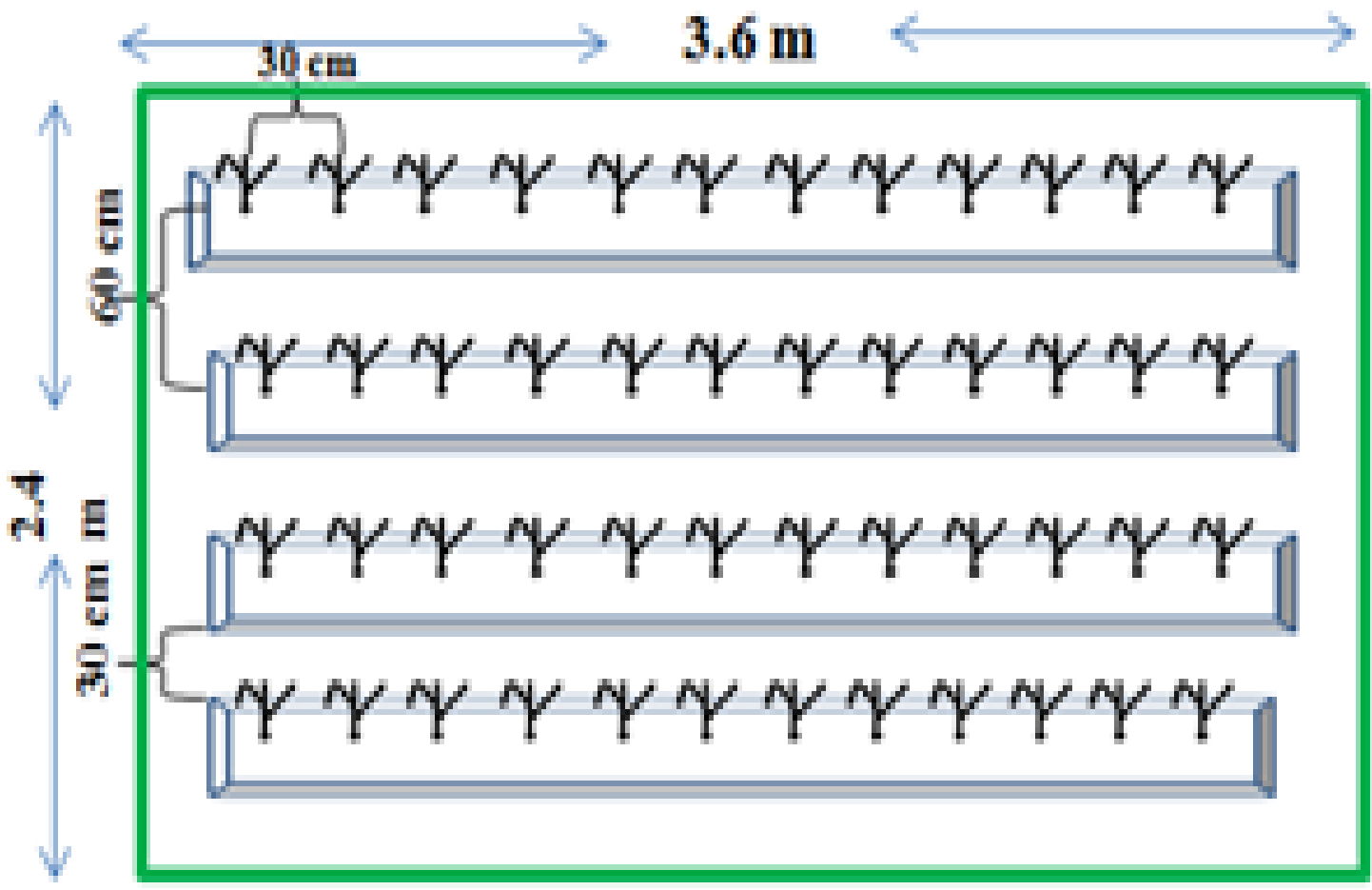




\section{Economics}

The minimum cost of cultivation was recorded in ridge planting, followed by FIRB and flatbed planting. However, the highest gross and net returns were filed in ridge planting, followed by FIRB and flatbed planting. It was $36 \%$, and $10.25 \%$ recorded more in ridge and FIRB planting over the flatbed planting method. At the same time, net return was $42 \%$ and $14 \%$ higher in ridge and FIRB as compared with flatbed planting method. Higher B:C ratio was observed in ridge planting, followed by FIRB and flatbed planting method, respectively.

The minimum cost of cultivation and maximum gross, net return, and $\mathrm{B}: \mathrm{C}$ ratio was observed with 30 days old seedlings, which was profitable to other age of seedlings, i.e., 20, 40, 50, and 60 days old. The 31January was the highest gross, net return, and B:C ratio, as compared to other treatments of harvesting.

The cultivation of crops like menthol mint, age of seedlings, planting method, and date of harvesting plays a vital role in crop yield and economics. Our study indicated that the ridge planting method is more advantageous than other methods due to better aeration and welldrained conditions during the cropping period. It might be due to proper oxic conditions and better management of water utilized by plants. This results in the agreement of Govaerts et al., (2005) has been proven that the raised bed cultivation system is better for a reduction in soil tillage and retention in crop residue. Similar confirmations were reported by Yaseen et al., (2013) on Cholorophytum borivilianum L. The transplanting of mentholmint on the furrow irrigated raised bed provided the highest fresh biomass yield, essential oil yield, and oil quality as compared with flat planting (Upadhayay et al., 2014). The maximum seed yield of soybean was recorded in a $6 \mathrm{~m}$ wide raised bed followed by $9 \mathrm{~m}$ raised bed and minimum in flat plots (Tomar et al., 1996). Mazeed et al., (2015); LimonOrtega et al., (2008) also reported that a raised bed requires improved nitrogen use efficiency and gave a yield of wheat (Triticum aestivum L.) over flatbed planting. Hence, the ridge planting could be considered as the better method of the planting of menthol mint as compared with FIRB planting and flatbed planting.

The highest herb yield in the combination of 30 days old seedling on the ridge planting, it may presumably be due to better aeration to root zone, and higher uptake of nutrients under ridge planting led to maximum rhizome yield and herb production during cropping period (Upadhyay et al., 2015).

There was a significant reduction in herb yield, essential oil content, oil yield, and menthol content with the enhancement of age of seedlings. Cultivation of crops like menthol mint, age of seedlings plays a crucial role in crop yield and economics. Our study implied the 30 days old seedlings are suitable for higher herb and essential oil production. It might be possible that phyllochronic potential of 30 days old seedlings resultant more growth traits are leading to the diversion of energy towards reproductive phases. This may cause increased yield attributes in menthol mint (Ram et al., 2014). It might be due to a minimum weed incident for 30 days old seedlings due to better growth of the crop. However, an increase in the age of seedlings, a decreasing trend in gross and net income, and an increasing trend in the cost of rhizome production was observed.(Thomas, 1998)also reported that the use of 21 days old plantlets of (Vitis vinifera L.) was more advantageous with enhanced vigor than the 28 days and 35 days old seedlings. 
It may be possible due to higher yield obtained from ridge planting with minimum water use and higher water use efficiency. The likely reason for a higher return in ridge planting is that by using this method, irrigation is reduced after first irrigation (i.e., at planting time). The irrigation is applied only upto half the height of ridges, which in turn reduces the water requirement in ridge planting as compared with FIRB and flatbed planting. Astatke et al., (2002) reported that broad bed furrow farming proved advantageous in regards to water saving, mechanical weeding, fertilizer placement, available moisture conservation, less lodging, and better crop stand. Similar results have also been reported in the rice-wheat cropping system under delayed sowing Naresh et al., (2012); Bhuyan et al., (2012). Raised planting is more advantageous over flatbed planting in terms of irrigation water requirement, improvement of nitrogen use efficiency, and microclimate within the field (Fahong et al., 2004).

The harvesting of menthol mint rhizome is an essential factor for its production. Generally, early digging may lead to a reduction in the rhizome yield due to a lack of sufficient period for growth and development of the planting material. Whereas, late digging allows adequate period and optimum temperature $\left(10-18^{\circ} \mathrm{C}\right)$ for more productivity of rhizome (planting material). The crop harvested on 15 December (early harvesting), which gave minimum values for essential oil content and yield. It is because of at early harvesting crop was not mature enough to yield more as well as not synthesized much essential in leaves. These results are similar to the findings of Sattayarak (1997); Knauft et al., (1986). It may be attributed to a change in weather conditions, due to the high temperature in delay harvesting (31 January) over to early harvesting. It is because of the initial date of harvesting leads to low rhizome yield, which in turn reduces the gross and net income of the crop. (Young et al., 1982) reported that an increase in growth period enhanced pod production in Pisum sativum L. However, the delay in harvesting resulted in a decline in harvested yield. It may be attributed to field losses. The delayed digging in Arachis hypogaea L. enhanced the quality of kernels, oil content, the percentage of shelling, and yield (Court et al., 1984).

Ridge and furrow irrigated raised bed planting was observed lower cost of cultivation. It might be due to fewer occurrences of weeds and against the dormancy of crop growth. An increase in gross return in the production of menthol mint by using this method was due to enhancement in the essential oil yield. Comparative net return was further higher in ridge planting due to a reduction in the cost of cultivation with an enhanced yield of essential oil. These results might be due to the cost of cultivation in the ridge, and FIRB planting had minimum because of minimum occurrences of weeds and better growth of crops during experimentation. It may be possible due to increases in the age of seedlings, decreases gross and net return, and increases the cost of cultivation. It isbecause of 30 days old seedlings were obtained higher rhizomes yield and essential oil yield, which reduces the cost of cultivation and enhances net returns. The delay in harvesting produced maximum gross and net profits. It might be due to low input, and maximum output was received at delay harvesting (Nilofer et al., 2018).

It is concluded from the present investigation that planting on the ridge was more profitable as compared with FIRB and flatbed planting. Ridge planting was observed higher yield, minimum water requirement, and maximum water use efficiency. The 30 days old seedling shown the maximum growth attributes, suckers, and essential oil yield along with 
reduced water and higher water use efficiency. Similarly, harvesting of suckers of menthol mint on 31January was observed as the maximum productivity and resource use efficiency.

Therefore, after the completion of the twoyear experiment, it was concluded that the ridge planting in combination with 30 days old seedlings plantation and harvesting on 31 January found best in terms of production of rhizome, essential oil. It is suggested that this technique will provide low inputs and high outputs for farmer communities.

\section{Acknowledgment}

The authors are cordially thankful to the Director, Central Institute of Medicinal and Aromatic Plants, Lucknow for providing necessary facilities to conduct experimental trials with financial supported by CSIRNetwork Project (BSC 0110).

\section{References}

Astatke A, Jabbar M, Saleem MM, Erkossa T., 2002. Technical and economic performance of animal-drawn implements for minimum tillage: experience on Vertisols in Ethiopia. Exp. Agric., 38 (2), pp.185-196.

Bhuyan, M.H.M., Ferdousi, M.R., Iqbal, M.T., 2012. Yield and growth response to transplanted Aman rice under the raised bed over conventional cultivation method. ISRN Agronomy, 2012.

Chand, S., Patra, N.K., Anwar, M., Patra., D.D., 2004.Agronomy and uses of menthol mint (Mentha arvensis) Indian perspective. Proceedings of the Indian National Science Academy Part B, Biological Sciences, 70 (3), pp. 269-297.

Clevenger, J.F., 1928. Apparatus for the determination of volatile oil. J. Am. Pharm. Assoc.17(4), pp. 345-349.

Court, W.A., Roy, R.C., Hendel, J.G., 1984. Effect of harvest date on agronomic and chemical characteristics of Ontario peanuts. Can. J. Plant Sci.64 (3), pp. 521-528.

Fang, W., Xuqing, W., Sayre, K., 2004. Comparison of conventional, flood irrigated, flat planting with furrow irrigated, raised bed planting for winter wheat in China. Field Crops Res. (1), pp.35-42.

Gan, Y., Siddique, K.H., Turner, N.C., Li, XG., Niu, J.Y., Yang, C., Liu, L., Chai, Q., 2013. Ridge-furrow mulching systems-an innovative technique for boosting crop productivity in semiarid rain-fed environments. Adv. Agron. (Vol. 118, pp. 429-476). Academic Press.

Govaerts, B., Sayre, K.D., Deckers, J., 2005. Stable high yields with zero tillage and permanent bed planting? Field CropsRes.94 (1), pp.33-42.

Guenther, T.G, Lovejoy, D.C., 1961. Analysis for Calculating Lateral Vibration Characteristics of Rotating Systems with Any Number of Flexible Supports: Part 2-Application of the Method of Analysis. J. Appl. Mech.28 (4), 591-600.

Jellani, G., Atif, M.J., Ullah, H., Ali, M., Musa, M., 2015. Influence of seedling age on cucumber Cucumis sativus $L$. production. J. Agric. 13(2), pp.214221.

Knauft, D.A., Norden, A.J., Gorbet., D.W., 1986. The effect of three digging dates on oil quality, yield and grade of five peanut genotypes grown without leafspot control. Peanut Sci. 13 (2), pp.82-86.

Kumar, R., Upadhyay, R.K., Venkatesha, K.T., Padalia, R.C., Tiwari, A.K., Singh, S., 2019. Performance of 
Different Parts of Planting Materials and Plant Geometry on Oil yield and Suckers Production of Menthol-mint (Mentha arvensis L.) during Winter Season. Int. J.Curr. Microbiol Appl. Sci. 8 (1), pp.1261-1266.

Limon-Ortega, A., Villaseñor-Mir, E., Espitia-Rangel, E., 2008. Nitrogen management and wheat genotype performance in a planting system on narrow raised beds. Cereal Res. Commun., 36 (2), pp.343-352.

Little, T. M., Hills, F.J., 1978. Agricultural experimentation: design and analysis (No. 630.72 L5).

Majeed, A., Muhmood, A., Niaz, A., Javid, S., Ahmad, Z.A., Shah., S.S.H., Shah, A.H., 2015. Bed planting of wheat (Triticum aestivum L.) improves nitrogen use efficiency and grain yield compared to flat planting. J. Crop Prod.3 (2), pp.118-124.

Naresh, R.K., Singh, B., Singh., S.P., Singh., P.K., Kumar, A., Kumar, A., 2012. Furrow irrigated raised bed (FIRB) planting technique for diversification of rice-wheat system for the western IGP region. Int. J. Life Sci. Biotech. Pharma Res. 1 (3), pp.134-141.

Nilofer, Singh, A.K., Singh, A., Singh, S., 2018. Impact of sowing and harvest times and irrigation regimes on the sennoside content of Cassia angustifolia Vahl. Ind. Crops and Prod.125, pp.482-490.

Nilofer, Singh, A.K., Singh, S., Gangwar, S.P., Singh, M., Singh, R., Yadav, A., 2015. Effect of weather conditions on growth, yield, and quality of Menthol mint Mentha arvensis L. cultivars transplanted in different years on different dates under the sub-tropical climate of North India. IJAAR. 6(2): 82-88.

Ram, H., Singh, J.P., Bohra, J.S., Singh, R.K.,Sutaliya., J.M., 2014. Effect of seedlings age and plant spacing on growth, yield, nutrient uptake, and economics of rice (Oryza sativa) genotypes under a system of rice intensification. Indian J. Agron., 59 (2), pp.256-260.

Ren, X., Cai, T., Chen, X., Zhang, P., Jia, Z., 2016. Effect of rainfall concentration with different ridge widths on winter wheat production under semiarid climate. Eur. J. Agron., 77, pp.20-27.

Sattayarak, S., Laosuwan, P., 1997. Effects of harvesting dates on different characters and seed quality of peanut grown in Southern Thailand. In 12.Thailand National Peanut Meeting, Udon Thani (Thailand), 2527 Oct 1994.

Sharma, R.S., Kumar, Y., Yadav, K., Patel, S., Raj, T., Yadav, V., Verma, R.S., Verma, D.K., Srivastava, R.K., Kumar, S., 2019. Performance evaluation of newly developed variety of menthol mint at farmer's field-A case study of mint cultivation in Central Uttar Pradesh. Agri. Sci. Dig. Res. J. 39 (1), pp.67-69.

Singh, S., Ram, M., Ram, D., Sharma, S., Singh, D.V., 1997. Water requirement and productivity of palmarosa on sandy loam soil under a sub-tropical climate. Agric. Water Manag. 35 (12), 1-10.

Singh, M., Singh, V.P., Singh, S., Saini, P., 2003. Optimum planting time and row spacing for bergamot mint (Mentha citrate Ehrh.) var. 'Kiran' under sub tropical plains of central Uttar Pradesh. Spices Aromat. Crops, 12 (2), 135-138

Thomas, P., 1998. The humid incubation period and plantlet age influence the acclimatization and establishment of micro propagated grapes. In Vitro Cellular \& Developmental BiologyPlant, 34 (1), pp.52-56. 
Tian, Y., Su, D., Li, F., Li, X., 2003. Effect of rainwater harvesting with ridge and furrow on the yield of potato in semiarid areas. Field Crops Res., 84 (3), pp. 385-391.

Tomar, S.S., Tombe, G.P., Sharma, S.K., Badawi, U.P.S., Tomar, V.S., 1996. Soil and water management, improvement of the physical condition of black soil in Madhya Pradesh. JNKVV, pp 26-47.

Upadhyay, R.K., Bahl, J.R., Verma, R.S., Padalia, R.C., Chauhan, A., Patra, D.D., 2014. A new source of planting material for quality cultivation of menthol-mint (Mentha arvensis L.). Ind. Crops Prod., 59, pp.184-188.

Yaseen, M., Singh, M., Singh, U.B., Singh, S., Ram, M., 2013. Optimum planting time, method, plant density, size of planting material and photosynthetically active radiation for Safed Musli (Chlorophytum borivilianum). Ind. Crops Prod., 43, pp.61-64.

Young, J.P.W., Matthews, P., 1982. A distinct class of Pisum sativum L. from Afghanistan that show strain specificity for symbiotic Rhizobium. Heredity, 48 (2), p. 203.

Zhou, L.M., Li, F.M., Jin, S.L., Song, Y., 2009. How two ridges and the furrow mulched with plastic film affect soil water, soil temperature, and yield of maize on the semiarid Loess Plateau of China. Field Crops Res., 113 (1), pp.41-47.

\section{How to cite this article:}

Devendra Kumar, Rakesh Kumar, Anil Kumar Singh, Kirti Verma, Kushal Pal Singh, Nilofer, Anuj Kumar, Parminder Kaur, Anjali Singh, Janhvi Pandey, Puja Khare and Saudan Singh. 2020. Influence of Planting Methods on Production of Suckers (Rhizome or Propagative Material), Essential Oil Yield, and Quality of Menthol Mint (Mentha arvensis L.). Int.J.Curr.Microbiol.App.Sci. 9(07): 3675-3689. doi: https://doi.org/10.20546/ijcmas.2020.907.431 